\title{
Needham and the Issue of Chinese as a Language for Science: Taking a Linguistic Turn Materially
}

\author{
Karine Chemla 林力娜
}

\begin{abstract}
Volume 7 of Joseph Needham's Science and Civilisation in China (SCC) gives the issue of Chinese language in scientific practice pride of place. Its arguments are mainly devised to oppose views, put forward by Marcel Granet in 1920 and then by Derk Bodde in the 1970s, to the effect that the Chinese script (for Granet) or "literary Chinese" (for Bodde) impeded the development of science. The essay outlines the way in which Christoph Harbsmeier, in Part 1 of Volume 7, and then Needham and Kenneth Robinson, in Part 2, expose the fallacies of these views. It suggests that Needham and Robinson's rebuttals to Bodde's position, innovative though they might be, share essential features with the latter's theses. In particular, they all view the Chinese language primarily from the viewpoint of its function of communicating knowledge. The essay argues that Chinese-writing communities of practitioners of mathematics constantly shaped technical languages that drew on but also added to the resources of the Chinese language available to them to pursue their goals. The technical languages thereby shaped were not simply a means of communication with fellow-practitioners; they were also a tool of work. In conclusion, the essay argues that a language and the work done with this language are co-constructed.
\end{abstract}

\section{LANGUAGE AND SCIENTIFIC ACTIVITY IN SCC}

Joseph Needham's Science and Civilisation in China (SCC), the publication of which began in 1954, includes contributions by many scholars. Such collaborations were not without conflict; in some cases, they failed altogether. This was most notably the case for the last volume, which was to focus on "The Social Background." Although work on it began at the latest in the 1960s, its second and final part (SCC, Vol. 7, Pt. 2: General Conclusions and Reflections) eventually appeared

\footnotetext{
Karine Chemla (SPHERE, CNRS, and University Paris Diderot; currently MPIWG, Department II, Berlin) published Les neuf chapitres: Le classique mathématique de la Chine ancienne et ses commentaires with Guo Shuchun (Dunod, 2004). She is the editor of The History of Mathematical Proof in Ancient Traditions (Cambridge, 2012); Texts, Textual Acts, and the History of Science (with Jacques Virbel) (Springer, 2015); The Oxford Handbook of Generality in Mathematics and the Sciences (with Renaud Chorlay and David Rabouin) (Oxford, 2016); and Cultures without Culturalism (with Evelyn Fox Keller) (Duke, 2017). Université Paris 7 CNRS, Laboratoire SPHERE UMR 7219 (ex-REHSEIS), Case 7093, 5 rue Thomas Mann, 75205 Paris, France; chemla@univ -paris-diderot.fr.

Acknowledgments. It is my pleasure to thank Dagmar Schäfer and Florence Hsia for their feedback on my project and the text for this Second Look section. The remarks offered by participants in the workshop organized at the Max Planck Institute, Berlin, in August 2018 were very useful for completing this text. I wrote this essay while benefiting from the generous hospitality of Lorraine Daston (Director of Department II, Max Planck Institute), as well as from the unflinching support of the librarians in Berlin. Sarah Kuehne and Joan Vandegrift offered advice to improve the final version. May all of them receive the expression of my deepest gratitude.
}

Isis, volume 110, number 1. (c) 2019 by The History of Science Society.

All rights reserved. 0021-1753/2019/0110-0008\$10.00. 
only in 2004, nearly ten years after Needham passed away. In the meantime, the scheme for Volume 7 had undergone several radical changes. ${ }^{1}$ In fact, the first plan for this volume had been to invite the American sinologist Derk Bodde to - as he put it-deal with "the many intellectual factors, either favorable or unfavorable, that [were] regarded as having significantly influenced China's scientific development down to roughly 1600." At the end of the 1970s, Bodde submitted a contribution for the seventh volume that covered all the topics that Needham had listed for it. However, this contribution elicited heated debates between Bodde and Needham, which led Bodde to withdraw his manuscript and publish a revised version as a separate book. ${ }^{2}$

The gulf separating Bodde's approach and the one adopted by Needham's team can be perceived in the slight differences between their various formulations of the purpose of Volume 7. As Kenneth Robinson's preface put it, the point of the volume was to address "factors that [Needham] felt formed part of the social background enabling or disabling the rise of science." ${ }^{3}$ Volume 7 also aimed at exposing certain prejudices that had been put forward in the past to account for "China's failure" to develop modern science. Prominent among these prejudices, which concentrated specifically on "intellectual factors," were persisting views about the inability of the Chinese language to serve as a tool for the development of science. This was the burning issue that led to the conflict between Bodde and Needham going out of control.

In SCC, Volume 7, as it now stands, discussion of the Chinese language and its use in the context of scientific activity is given pride of place. It is to this issue that the main new piece of Part 2 is devoted - that is, a formerly unpublished chapter by Robinson and Needham entitled "Literary Chinese as a Language for Science." ${ }^{4}$ Moreover, Part 1 of Volume 7, authored by Christoph Harbsmeier under the title Language and Logic, also addresses this question. ${ }^{5}$ According to Robinson's recollections, "the role of the classical language of China in relation to science" was precisely one of "the two main differences in points of view" between Bodde and Needham, for which "compromise was not possible" and which led to the eventual eviction of Bodde's contribution from SCC. ${ }^{6}$ Bodde's view of the disagreement concurs; he even describes as the "first" among "the differing opinions" between himself and Needham "the question of whether or not the Chinese written language had historically functioned effectively as a medium for the exposition of topics relevant to science."

\footnotetext{
${ }^{1}$ See Kenneth Girdwood Robinson, "Volume Editor's Preface," in Science and Civilisation in China, Vol. 7: The Social Background, Pt. 2: General Conclusions and Reflections, ed. Robinson, with contributions from Ray Huang (Cambridge: Cambridge Univ. Press, 2004) (hereafter cited as SCC, Vol. 7, Pt. 2), pp. xvii-xxiii, esp. pp. xix-xxii.

${ }^{2}$ Derk Bodde, Chinese Thought, Society, and Science: The Intellectual and Social Background of Science and Technology in PreModern China (Honolulu: Univ. Hawaii Press, 1991); the quotation is from p. 2 (emphasis added).

${ }^{3}$ Robinson, "Volume Editor's Preface" (cit. n. 1), p. xix (emphasis added).

${ }^{4}$ Kenneth Robinson and Joseph Needham, "Literary Chinese as a Language for Science," in SCC, Vol. 7, Pt. 2, pp. 95-198. Note that a shorter version of this chapter was published earlier as Needham and Robinson, "Literary Chinese as Scientific Language: A Selection for the Concluding Volume of Science and Civilisation in China, with Illustrations," in Comparative Criticism, Vol. 13: Literature and Science, ed. E. S. Shaffer (Cambridge: Cambridge Univ. Press, 1991), pp. 3-30. The prefatory note on p. 3 describes the relationship between the two publications.

${ }^{5}$ Harbsmeier provides a historical overview of views about the Chinese language, to which I will return. Joseph Needham, Science and Civilisation in China, Vol. 7, Pt. 1: Language and Logic in Traditional China, by Christoph Harbsmeier, ed. Kenneth Girdwood Robinson (Cambridge: Cambridge Univ. Press, 1998) (herafter cited as SCC, Vol. 7, Pt. 1), pp. 8-26.

${ }^{6}$ Robinson, "Volume Editor's Preface" (cit. n. 1), p. xx.

${ }^{7}$ Bodde, Chinese Thought, Society, and Science (cit. n. 2), p. 2 (emphasis added). I vividly remember visiting Joseph Needham's Institute in Cambridge between 1980 and 1984 and discussing this issue with Kenneth Robinson, at a time when he and Needham were preparing refutations of some of Bodde's arguments allegedly proving that the Chinese language was an unsuitable vehicle for scientific activity.
} 


\section{WHAT IS AT STAKE FOR THE HISTORY OF SCIENCE?}

I insist on these facts because they clearly show that, for Needham, the issue of language in scientific practice was a vital one. One might have the impression that, in a history of science practiced at a global level, issues that obsessed Needham have recently resurfaced as being of some importance. Michael Gordin, for instance, has forcefully returned language issues to the fore with his excellent Scientific Babel. In this book, he focuses on the history of the languages in which, from the second half of the nineteenth century, science (more specifically, chemistry) was predominantly practiced and published - and also on how actors perceived these languages and their use. One of his main goals is to deal with the history and consequences of linguistic domination in scientific practice, especially with the rise of English as a global language for science. Even more recently, in the Isis Focus section that Gordin edited in 2017, the issue of "Linguistic Hegemony and the History of Science," together with that of actual multilingualism in scientific practice, was approached at a more global level. ${ }^{8}$ However, one remark will suffice to indicate that the precise problem of language that was so essential for Needham is not prominent in these recent publications.

In these new approaches to language issues in the history of science, the so-called Sapir-Whorf hypothesis, as well as cognate theses, remains a minor concern. ${ }^{9}$ In simple terms (it actually admits of stronger or milder formulations), that hypothesis holds that a speaker's native language shapes the thought (and, in particular, the science) that he or she produces. A related thesis asserts that some languages are better suited for scientific activity than others. By contrast with these recent works, the language issues regarding which, for Needham, no compromise was possible were all related to the Sapir-Whorf hypothesis. A concern of this kind is also of central importance for Roger Hart and in the recent forum about language issues in the practice of science published in the journal East Asian Science, Technology, and Society (EASTS) in $2017 .{ }^{10}$ It is no accident that in all these cases, the historians active in bringing these issues to the fore were involved in the history of science in China. This does not mean that the issues are not general. The related problems are simply more conspicuous when one works on a region of the planet like China. As far as I can tell, however, there has been no systematic effort to tackle this problem in the history of science at large, in the way Needham wanted to address it. It is my conviction that, in the context of a global history of science, it remains for us today a key issue that warrants further research. Let me explain why and how.

\section{NEEDHAM'S OPPONENTS AMONG SINOLOGISTS}

Sinology and the history of science in China have abounded - and still abound - in specialists for whom - for example - the inability of "the Chinese" to develop "science" (or to develop it in a correct way) derived from alleged deficiencies of "the Chinese language." "Bodde was one

\footnotetext{
${ }^{8}$ Michael D. Gordin, Scientific Babel: How Science Was Done Before and After Global English (Chicago: Univ. Chicago Press, 2015); and Gordin, ed., "Focus: Linguistic Hegemony and the History of Science," Isis, 2017, 3:606-650, with contributions by Elena Aronova, Sietske Fransen, Gordin, Ahmad Ragab, Mary Terrall, and Dagmar Schäfer.

${ }^{9}$ Gordin, Scientific Babel, invokes the Sapir-Whorf hypothesis briefly (pp. 14-15, 197-198, 314). Endnote 26 (p. 335 ) argues that the names associated with the hypothesis should be revised. Since I am unable to settle this question, I use the common denomination here. For the related thesis see ibid., pp. 2-3, 196-198.

${ }^{10}$ Roger Hart, "From Copula to Incommensurable Worlds," in Imagined Civilizations: China, the West, and Their First Encounter (Baltimore: Johns Hopkins Univ. Press, 2013), pp. 51-75; and Kuo Wenhua, ed., "Forum: Keller on Language, Science, and Globalization," East Asian Science, Technology, and Society (EASTS), 2017, 11:373-419, which is constituted of responses to an article by Evelyn Fox Keller, "Globalization, Scientific Lexicons, and the Future of Biology," along with an introduction by Fu Daiwie, contributions by Francesca Bray, Ruey-Lin Chen, Tomoko Ishida, Dayk Jang, and Karine Chemla, and a response from Fox Keller.

${ }^{11}$ Hart, "From Copula to Incommensurable Worlds," pp. 53-57, introduces examples, which he then discusses.
} 
of them, but the phenomenon started much earlier. Needham, and other contributors to SCC, considered it essential to stand up to such views. Long before Bodde wrote his contested contribution to SCC in the 1970s, the influential China specialist Marcel Granet (1884-1940) published an article entitled "Some Particularities of the Chinese Language and Chinese Thought." In it Granet explained that, in his view, the advancement of science had been made possible in Europe thanks to the availability of specific European languages. For him, these languages were characterized by the fact that they offered appropriate tools that enabled scientists to define and enact classifications. Moreover, he suggested, they made logical thinking and the transmission of "clear and distinct thought" easier. ${ }^{12}$

By contrast, the Chinese language seemed to Granet to be lacking all these properties and hence to be inappropriate for the "practice of scientific research." His view was that these problems were caused by the language's lack of morphology, which he attributed to its being written with Chinese characters. Writing at a time when Chinese intellectuals were working on a reform of the Chinese language, he plainly suggested to them that, if they wanted science and the "esprit positif" to develop in Chinese, they should change the script and get rid of the characters so that morphology could develop. This, for him, was a sine qua non for the advancement of science in Chinese. ${ }^{13}$ There is no better way of showing the impact of Granet's views on twentieth-century sinologists and historians of science than this: almost a century later, in a section of Language and Logic entitled "The Question of the Suitability of the Chinese Language for Science," Christoph Harbsmeier defined the project of his volume as contradicting, point by point, the views Granet had presented in his 1920 article. $^{14}$

Harbsmeier was writing as a linguist and a historian of logic in China, having been invited to contribute his volume after it became clear that Bodde would withdraw his manuscript. In his foreword to the volume, Needham drew the conclusion that imposed itself from Harbsmeier's contribution, asserting: "Literary Chinese was no vague and poetic language unsuitable for science, provided it was used by a competent scientific thinker." ${ }^{15}$ But for Needham, the program of exposing fallacious views about the role of the Chinese language in impeding the advancement of science was not yet completed. He concluded his foreword to Harbsmeier's study with the following announcement: "Granted that Literary Chinese was capable of expressing scientific ideas, what actually happened when it was so used? This, as the Americans would say, is a whole new ball-game for which the reader will have to await a subsequent volume."16 This declaration corresponded to his coauthored contribution published in General Conclusions and Reflections, which had been written partly in opposition to views presented this time not by Granet but by Bodde.

Needham and Robinson developed an approach to the question that, to my knowledge, had never been embraced before. Capitalizing on all the work that had been done in the previous decades to prepare the publications of earlier volumes of SCC, they started with a conviction that might seem obvious to us but that (to say the least) was by no means universally accepted at the time: that Chinese scholars had actually carried out knowledge activities and that they had, in

\footnotetext{
12 Marcel Granet, "Quelques particularités de la langue et de la pensée chinoises," Revue Philosophique de la France et de l'Étranger, 1920, no. 89, pp. 98-128 (Pt. 1), 161-195 (Pt. 2), on pp. 189-190. The essay was republished in Granet, Etudes sociologiques de la Chine (1953; Paris: Presses Univ. France, 1991).

${ }^{13}$ Ibid., p. 193. For a more detailed analysis of Granet's views, and the evidence on which he based them, see Karine Chemla, "Penser sur la science avec les mathématiques de la Chine ancienne," in La pensée en Chine aujourd'hui, ed. Anne Cheng (Paris: Gallimard 2007), pp. 353-386, 432-438.

${ }^{14}$ SCC, Vol. 7, Pt. 1, pp. 22-24.

${ }^{15}$ Robinson, "Volume Editor's Preface" (cit. n. 1), p. xx (on Bodde's withdrawal); and Joseph Needham, "Foreword," in SCC, Vol. 7, Pt. 1, pp. xvii-xx, on p. xviii (emphasis added).

${ }^{16}$ Needham, "Foreword," in SCC, Vol. 7, Pt. 1, pp. xix (emphasis added). Joachim Gentz and Dirk Meyer, eds., Literary Forms of Argument in Early China (Leiden: Brill, 2015), is for me an endeavor along similar lines.
} 
this context, obtained results and composed writings that were scientifically meaningful. As a result, to approach the issue of the relationship between "the Chinese language" and "science," Needham and Robinson were able to focus on the Chinese language that could be observed in actual scientific texts. This was what they in fact set out to do. Again, proceeding in this way seems to us to make perfect sense. Interestingly, this was not at all how Granet and then Bodde had worked to reach their conclusions.

Like Granet, Bodde essentially examined "the Chinese written language" (whose difference from spoken Chinese he duly emphasized) in canonical texts from antiquity, and on this basis he likewise generalized to the conclusion that "written Chinese has, in a variety of ways, hindered more than it has helped the development of scientific ways of thinking in China." Clearly, the possibility of drawing a conclusion of this kind rested on the implicit assumption that the features of "the Chinese written language" under scrutiny remain unchanged, whether one considered them in different time periods or in different social milieus. It thus comes as no surprise that Bodde held that "the written language has contributed ... to the continuity, spread and homogeneity of Chinese civilization" and that it "gave China a cultural continuity in time and unity in space." Indeed, he went much further, stating: "The script and literary language were also barriers to the proper understanding - let alone adoption - of foreign ideas. Furthermore, if it be true that science prospers in an atmosphere of intellectual diversity, one might argue that the cultural uniformity that was encouraged ... by the use of a common literary language, could well have been unfavorable to original scientific thought."17

Confronted with assertions of this kind, Needham could not remain silent. The piece he coauthored with Robinson aimed at providing evidence to support opposing views. Needham and Robinson's emphasis on the terminology proper to scholarly milieus that practiced botany and mathematics, and on the neologisms that enabled the translation of scientific works coming from Europe into Chinese from the seventeenth century onward, can be interpreted as concrete rebuttals to Bodde's assertions. ${ }^{18}$

\section{FURTHER ISSUES IN THE STUDY OF CHINESE LANGUAGES IN SCIENTIFIC PRACTICE}

Although Needham and Robinson opened the way to an analysis of the use of the linguistic means put in play for the practice of science to which Chinese documents attest, their joint text only scratches the surface of the subject. Much remains to be done in this direction, and I agree with Needham that we cannot leave the topic unattended, given how widespread beliefs are about the obstacles that allegedly have impeded and continue to impede scientific practice in Chinese (notwithstanding the manifest changes that the language has undergone). In my view, however, the orientation that Needham gave to this line of inquiry needs to be rethought and extended.

Some remarks suffice to make this point clear. It is symptomatic that, although Robinson and Needham set out to oppose Bodde's views, their methodologies shared similar features and they in fact embraced some of the tacit assumptions on which his theses relied. Indeed, like Bodde,

\footnotetext{
${ }^{17}$ Bodde, Chinese Thought, Society, and Science (cit. n. 2), pp. 96, 28 (emphasis added), 29. The chapter entitled “The Dynamics of Written Chinese," in which we find the conclusion that written Chinese has hindered the development of scientific thinking in China, deserves a much longer analysis than I am able to give here. It presents a collection of prejudices about both science and language that would be worth discussing further. Note that despite similarities between the two sinologists' conclusions, Granet focuses on the writing system as the main explanatory factor. See Chemla, "Penser sur la science avec les mathématiques de la Chine ancienne" (cit. n. 13), pp. 433 n 7, 433-434 n 13.

18 This line of inquiry was further developed in, e.g., Michael Lackner, Iwo Amelung, and Joachim Kurtz, eds., New Terms for New Ideas: Western Knowledge and Lexical Change in Late Imperial China (Leiden: Brill, 2001); and Lackner and Natascha Vittinghoff, eds., Mapping Meanings: The Field of New Learning in Late Qing China (Leiden: Brill, 2004).
} 
Robinson and Needham aimed at assessing language from the viewpoint of how it fared with respect to precision, accuracy, and clarity. This choice was correlated with a common focus on the ability of "the Chinese language" to enable communication in scholarly matters, a quality they considered that they (as observers) could and should judge. ${ }^{19}$

However, there is one type of episode in the history of science in China that Needham and Robinson do not mention and that nevertheless exposes fundamental weaknesses in Bodde's reasoning that they leave unremarked. Consider the algebra that Chinese practitioners active in Hebei province developed at least from the thirteenth century onward. This form of algebra, to which writings spanning several decades attest, seems to have remained unknown to scholars who were based in the southern part of China and whose writings about mathematics have come down to us. What is more, although the writings that testify to the shaping of this form of algebra were in literary Chinese, by the sixteenth century they had become incomprehensible for scholars versed in mathematics who had the opportunity to read them. ${ }^{20}$ These texts and their various fortunes suggest that the uniformity and the continuity that in Bodde's view derived from the use of "the Chinese written language" cannot be taken for granted a priori. More specifically, this episode provides evidence about the difficulties historical actors encountered when attempting to work with historically specific forms of written communication. Do these difficulties arise because of problems with "the Chinese language"? The fact is that, for the purposes of their mathematical investigations, the practitioners of this particular form of algebra had developed specific concepts and, accordingly, a specific language, which included (but was not reduced to) a symbolic notation. Later practitioners, who had not been acculturated to this way of working, could understand neither the form of reasoning nor the terminology, let alone the symbolic writing. Moreover, were we tempted to incriminate the symbolic notation in this problem of communication, another episode of the same kind would suffice to show the limits of this view. The first-century Chinese classic The Nine Chapters on Mathematical Procedures testifies to substantial mathematical work with algorithms, which went along with the shaping of technical ways of using the Chinese language. Here, too, actors' mathematical work went hand in hand with the elaboration of a specific language. In this case, the actors' texts use only Chinese characters, but in an idiosyncratic fashion. Interestingly, when Yang Hui composed a commentary on The Nine Chapters in 1261, he made explicit several technical features of the language, which suggests that by that time they needed to be explained to readers. Moreover, he failed to identify one key technique, which led him to misinterpret algorithms using a specific mode of expression. ${ }^{21}$ Here again, we see how prob-

\footnotetext{
${ }^{19}$ These two features are manifest in this statement by Bodde: "To what extent has the Chinese language, and especially literary Chinese, encouraged or inhibited the accurate and clear communication of facts and ideas, and thereby the development of scientific ways of thinking?" Bodde, Chinese Thought, Society, and Science (cit. n. 2), p. 32 (emphasis added). Needham and Robinson's emphasis on the three properties mentioned and on communication are evidenced, respectively, in "Literary Chinese as a Language for Science" (cit. n. 4), pp. 95 n 1, 99, 103; pp. 104, 115; pp. 122, 166; p. 103. See also Needham and Robinson, "Literary Chinese as Scientific Language" (cit. n. 4), pp. 10, 11, 9, 3. Interestingly, "communication" is also a focus of Gordin's approach to language.

${ }^{20}$ This episode is well known to anyone knowledgeable about the history of mathematics in China. The reader can consult any general book on the topic; in particular, see Joseph Needham, Science and Civilisation in China, Vol. 3: Mathematics and the Sciences of the Heavens and the Earth, with Wang Ling (Cambridge: Cambridge Univ. Press, 1959), "Section 19: Mathematics," pp. 44-45, 51, 129 133.

${ }^{21}$ See Karine Chemla, "Reading and (Re-)Classifying Canonical Instructions of the Past: Commentaries on "The Nine Chapters on Mathematical Procedures' from the Third to the Thirteenth Centuries," History of Knowledge, 2018, https:// historyofknowledge.net/2018/06/05/reading-and-re-classifying-canonical-instructions-of-the-past-commentaries-on-the-nine-chap ters-on-mathematical-procedures-from-the-3rd-to-the-13th-centuries/ (posted 5 June 2018). I am developing this contribution into an article. See all the contributions at https:/historyofknowledge.net/lbtb/.
} 
lematic the views claiming that language "gave China a cultural continuity in time and unity in space ..." in fact are.

These two episodes lead me to a general observation, which I believe holds true far beyond China and articulates a research program that would push forward what Needham had in mind. In pursuing their goals, Chinese-writing communities of practitioners of mathematics constantly shaped technical languages that drew on but also added to the resources of the Chinese language. Investigating how they put in play and modified these resources seems to me a project worth undertaking, the better to understand the flexibility of cultural resources like language in the hands of practitioners. The technical languages thereby shaped, precisely because they meshed with the scientific activity being carried out, constitute a series of temporary elaborations that underwent constant change in conjunction with the social group using them.

For historical actors, these many forms of Chinese were not simply a means of communication with fellow practitioners. They were also a tool of work, a dimension all too often forgotten in discussion about language in scientific practice. How did collectives of actors shape and reshape such languages, and how did they work with them? This is how I suggest reformulating the question that appeared so essential to Needham - and rightly so, in my view. Addressing this question would be a way of exposing the illusion, conveyed by the Sapir-Whorf hypothesis, that a language is something fixed that leaves its mark on the thought activities carried out using it. Scientific activity reveals how a language and the work done with this language are co-constructed. Thought might shape its language in the same process that this language shapes the thought produced through operating with it. 